\title{
HUBUNGAN ANTARA MOTIVASI BELAJAR DENGAN MINAT BELAJAR SISWA KELAS IV SDN PORIS GAGA 05 KOTA TANGERANG
}

\author{
Amni Fauziah ${ }^{1}$, Asih Rosnaningsih' ${ }^{2}$, Samsul Azhar ${ }^{3}$ \\ ${ }^{1,2,3}$ Program Studi Pendidikan Guru Sekolah Dasar \\ Universitas Muhammadiyah Tangerang \\ 'Amniefauziah@gmail.com \\ 2asihrosna@gmail.com
}

\begin{tabular}{ll}
\hline $\begin{array}{l}\text { Informasi artikel } \\
\text { Sejarah artikel }\end{array}$ & \\
Diterima & $: 18 / 10$ \\
Revisi & $: 16$ \\
Dipublikasikan & $: 28 / 12 / 2107$ \\
Kata kunci: & \\
Motivasi belajar, & \\
minat belajar, & \\
siswa kelas IV &
\end{tabular}

\begin{abstract}
ABSTRAK
Minat merupakan sebuah awal penggerakan untuk siswa dalam belajar yang dapat digunakan untuk mencapai tujuan yang diingkinkan. Tujuan dalam kaitan ini adalah tujuan pembelajaran. Tujuan penelitian ini adalah untuk mengetahui apakah terdapat hubungan antara motivasi belajar dengan minat belajar siswa kelas IV SDN Poris gaga 05 Kota Tangerang.

Penelitian ini dilakukan dengan pendekatan kuantitatif korelasi pada siswa SD Kelas IV. Sampel pada penelitian ini adalah 54 siswa kelas IV yang terdiri dari kelas IVA dan IVB. Data dikumpulkan dengan observasi, wawancara dan angket.

Hasil penelitian menunjukkan bahwa terdapat hubungan yang signifikan antara motivasi belajar dengan minat belajar siswa kelas IV SDN Poris gaga 05 Kota Tangerang dengan nilai $r$ hitung 0,889 lebih besar dari $r$ tbel 0,264 atau 0,89>0,264 dengan tingkat hubungan sangat kuat. 2) Terdapat hubungan yang positif antaar motivasi belajar dengan minat belajar siswa kelas IV SDN Poris gaga 05 Kota Tangerang dengan koefisien determinasi yaitu 0,889 x 0,889 x $100=0,791 \%$.
\end{abstract}

Key word:

motivation to learn, interest in learning, elementary students

\section{ABSTRACT}

The purpose of this study is to determine whether there is a relationship between learning motivation with the interest of students in grade IV SDN Poris gaga 05 Kota Tangerang. This research was conducted by correlational quantitative approach in grade 4 elementary school students. The sample in this research is 54 students of class IV consisting of class IVA and IVB. Data collection conducted by observation, interview and questionnaire. The results of this study indicate that there is a significant relationship between learning motivation with the interest of students in grade IV SDN Poris gaga 05 with coefficient determination value $79.1 \%$.

\section{Pendahuluan}

Pendidikan merupakan kegiatan yang dilakukan dengan sengaja agar anak didik memiliki sikap dan kepribadian yang baik, sehingga penerapan pendidikan harus diselenggarakan sesuai dengan sistem pendidikan nasional. Dalam hal ini penentu kualitas pendidikan adalah ketika bagaimana pendidikan itu disampaikan di tingkat sekolah dasar. Karena itulah pada saat pendidikan dasar pengembangan akan potensi siswa harus lebih diperhatikan dan diarahkan dengan baik. 
Sekolah yang merupakan lembaga pendidikan formal, harus mampu mengembangkan seluruh potensi yang dimiliki oleh peserta didik. Sekolah merupakan lembaga yang bersifat kompleks dan unik. Bersifat kompleks karena sekolah sebagai organisasi memiliki berbagai dimensi yang satu sama lainnya saling berkaitan dan saling menunjang. Bersifat unik karena sekolah memiliki karakter tersendiri, dimana didalamnya terdapat proses belajar mengajar, tempat terselenggaranya pembudayaan yang ditunjukkan bagi peningkatan kualitas dan pengambangan potensi peserta didik. Potensi peserta didik tersebut meliputi aspek kognitif, afektif, dan psikomotor. Sekolah sebagai lembaga pendidikan yang dapat mengubah cara berpikir, pola hidup, kebiasaan, dan tata cara pergaulan. Guru merupakan fasilitator dalam pendidikan di sekolah dan dapat meningkatkan siswa dalam prestasi belajar. Selain guru ada faktor yang mempengaruhi proses belajar siswa, yaitu: Faktor Internal dan Faktor Eksternal. Faktor internal biasanya terdiri atas intelegensi, minat, bakat, motivasi, mental dan perhatian, dan faktor eksternal terdiri dari lingkungan sekolah, keluarga, dan masyarakat.

Dalam proses pembelajaran, minat merupakan sebuah awal penggerakan untuk siswa dalam belajar yang dapat digunakan untuk mencapai tujuan yang diingkinkan. Tujuan dalam kaitan ini adalah tujuan pembelajaran. Hal ini menggambarkan bahwa seseorang yang memiliki minat belajar dalam dirinya maka dia akan mencapai keinginan atau cita-citanya, tetapi jika seorang siswa tidak memiliki minat dalam belajar maka siswa tersebut tidak akan bisa mencapai keinginan atau cita-citanya. Minat belajar siswa sangat dibutuhkan dalam pemebelajaran, agar siswa tersebut mempunyai ketertarikan terhadap materi yang diajarkan. Selain minat siswa juga membutuhkan dorongan atau gerakan untuk mencapai tujuannya atau cita-citanya.

Motivasi merupakan salah satu faktor yang sangat penting untuk mendorong semangat belajar siswa. Di dalam motivasi juga terdapat keinginan dan cita-cita yang tinggi. Sehingga siswa yang mempunyai motivasi belajar akan mengerti dengan apa yang menjadi tujuan dalam belajar, disamping itu keadaan siswa yang baik dalam belajar akan menyebabkan siswa tersebut semangat dalam belajar dan mampu menyelesaikan tugas dengan baik.

Motivasi merupakan dorongan seseorang secara sadar atau tidak sadar untuk melakukan sesuatu kegiatan untuk mencapai tujuannya. Motivasi juga bisa berasal dari dalam diri dan dari orang lain, baik itu guru, keluarga dan teman. Siswa yang memiliki motivasi belajar maka akan serius dan tertarik dalam pembelajaran sehingga siswa mendapatkan hasil belajar yang memuaskan, tetapi siswa yang tidak memiliki motivasi belajar maka akan selalu merasa bosan dalam pembelajaran. Peran motivasi dalam proses pembelajaran, motivasi belajar siswa dapat dianalogikan sebagai bahan bakar untuk menggerakkan mesin. Motivasi belajar yang memadai akan mendorong siswa berperilaku aktif untuk berprestasi dalam kelas, tetapi motivasi yang terlalu kuat justru dapat berpengaruh negatif terhadap keefektifan usaha belajar siswa.

Guru profesional harus bisa menggali apa saja yang mampu membangkitkan minat dan motivasi peserta didik. Namun terkadang setiap mata pelajaran berbeda-beda tingkat kesulitannya. Dan bakat siswa juga berbeda-beda. Jadi untuk membangkit semua minat dan motivasi belajar dalam satu mata pelajaran yang sama itu sulit, tetapi tugas seorag guru yang profesional harus bisa melakukannya, agar proses pembelajaran berjalan baik dan aktif. Dengan adanya dorongan belajar yang sangat kuat terutama dari guru, siswa semangat dan bergairah untuk belajar. Dan siswa pun mampu menerima, memahami, dan menguasai materi pelajaran yang harus dikuasainya. Siswa yang mampu mengerjakan tugas-tugas akan mencapai prestasi belajar dengan baik.

Pada kenyataan dilapangan, masih banyak guru yang tidak dapat memotivasi dan membangkitkan minat peserta didik dalam belajar. Hal tersebut dibuktikan dengan hasil observasi peneliti ke SDN Poris Gaga 05 pada Kelas IV, yaitu : Pertama, siswa masih rendah minat dalam belajar, Kedua, masih banyak siswa yang tidak termotivasi dalam mengikuti pembelajaran, Ketiga, banyak siswa yang 
hanya mau belajar sesuai bakatnya, Keempat, banyak sekali guru yang tidak mempersiapkan proses pembelajaran dengan baik.

Berdasarkan latar belakang tersebut maka peneliti akan menggunakan minat belajar dan motivasi belajar, Karena kurangnya minat dan motivasi belajar pada siswa kelas IV Sekolah Dasar (SD) membuat proses pembelajaran tidak efektif, maka seorang guru harus bisa membangkitkan dan meningkatkan minat belajar dan motivasi belajar siswa agar proses pembelajaran menjadi efektif dan mendapat hasil belajar yang diinginkan. karena minat dan motivasi merupakan hal yang paling penting dalam diri setiap manusia supaya terpacainya tujuan yang dituju oleh seseorang, terutama pada dalam diri siswa untuk mempunyai rasa semangat yang tinggi untuk belajar dan meraih prestasi yang baik. Dan penelitian ini di susun dalam skripsi dengan judul "Hubungan Antara Motivasi Belajar Dengan Minat Belajar Siswa Kelas IV SD Negeri Poris Gaga 05 Kota Tangerang”

\section{Kajian Teori}

\section{Minat belajar}

Minat memegang peranan penting dalam segala hal, karena dengan adanya minat seorang anak akan lebih bersemangat dalam melakukan sesuatu tanpa merasa adanya paksaan. Seperti yang dinyatakan oleh Bloom (1982: II7) bahwa "Minat adalah apa yang disebutnya sebagai subject-related affect, yang didalamnya termasuk minat dan sikap terhadap materi pelajaran” (Susanto, 2016: 59). Untuk seorang anak yang sangat muda, lamanya minat dalam kegiatan tertentu sangatlah pendek. "Minat senantiasa berpindah-pindah namun demikian ia menghendaki keaktifan. Ia kerap kali mendasarkan kegiatan-kegiatannya atas pilihannya sendiri dan dapat lebih suka mengusahakan sesuatu tertentu daripada yang lainnya" (Djamarah, 20I I: I93)

Menurut Lester D.Crow dan Alice Crow (I958) menyatakan "Belajar adalah perolehan kebiasaan, pengetahuan, dan sikap termasuk cara baru untuk melakukan sesuatu dan upaya-upaya seseorang dalam mengatasi kendala atau menyesuaikan situasi yang baru" (Khodijah, 20I4, h. 48). "Tingkah laku yang mengalami perubahan karena belajar menyangkut berbgai aspek kepribadian, baik fisik maupun psikis, seperti perubahan dalam pengertian, pemecahan suatu masalah/berpikir, keterapilan, kecakapan, kebiaaan maupun sikap" (Purwanto, 2013, h. 85). Belajar yang merupakan proses kegiatan untuk mengubah tingkah laku si subjek belajar, ternyata terdapat beberapa faktor yang mempengaruhinya. Faktor tersebut dibagi menjadi 2, yaitu : faktor ekstern (dari luar) dan faktor intern (dari dalam). Faktor intern yang mempengaruhi belajar salah satunya adalah motivasi dan minat.

Minat akan selalu terkait dengan persoalan kebutuhan dan keinginan. Dalam kaitannya dengan belajar, Hansen (1995) menyatakan bahwa "Minat belajar siswa erat hubungannya dengan kepribadian, motivasi, ekspresi dan konsep diri atau identifikasi, faktor keturunan dan pengaruh eksternal atau lingkungan" (Susanto, 20016: 57). Minat terhadap sesuatu dipelajari dan mempengaruhi belajar selanjutnya serta mempengaruhi penerimaan minat-minat baru. Jadi "Minat terhadap sesuatu merupakan hasil belajar dan menyokong belajar selanjutnya” (Slameto, 2013:180).

Dalam proses pembelajaran seorang peserta didik harus mempunyai minat dalam belajar. Menurut (Prahmadita, 20I4: I2) dalam meningkatkan minat belajar terdapat beberapa faktor yang mempengaruhinya, yaitu : I)Faktor Internal yang terdiri dari a) Motivasi, Minat seseorang akan semakin tinggi bila disertai motivasi, baik yang bersifat internal maupun eksternal, b) Cita - Cita, Setiap manusia memiliki cita-cita dalam hidupnya, termaksuk para siswa, c) Bakat, Di samping intelegensi, bakat merupakan faktor yang besar pengaruhnya terhadap proses dan hasil belajar seseorang. 2) Faktor eksternal yang terdiri dari a) Guru, Menurut Singer (I99I) bahwa guru yang berhasil membina kesediaan belajar murid-muridnya, b) Keluarga, Orang Tua adalah yang terdekat dalam keluarga, oleh karena itu keluarga sangat berpengaruh dalam menentukan minat seorang siswa terhadappelajaran c) Teman Pergaulan, Melalui pergaulan, siswa dapat terpengaruh arah minatnya 
oleh teman-temanya, khususnya teman akrab, d)Lingkungan, Lingkungan sangat berperan dalam pertumbuhan dan perkembangan anak.

Setiap jenis minat berpengaruh dan berfungsi dalam pemenuhan kebutuhan, sehingga semakin kuat terhadap kebutuhan sesuatu, makin besar dan dalam minat terhadap kebutuhan tersebut. Menurut Slameto (1995: 54) menyebutkan "Bahwa intensitas kebutuhan seseorang secara signifikan terhadap besarnya minat individu yang bersangkutan” (Susanto, 2013: 63) Jadi seorang siswa akan berminat mempelajari masalah-masalah sosial, bilamana intelegensinya telah berkembang sampai pada taraf yang diperlukan untuk memahami dan menganalisis fakta dan gejala sosial dalam kehidupan seharihari. bisa saja seorang anak berminat terhadap sesuatu yang sebelumnya tidak mereka minati, namun karena penaruh teman sebayanya akhirnya berminat. Karena dari kebiasaan tersebut si anak meniru yang akhirnya menjadi kesenangan yang bersifat tetap yaitu minat.

\section{Motivasi Belajar}

Motivasi merupakan dorongan untuk seseorang melakukan sesuatu untuk mencapai tujuan tertentu. Menurut Mc.Donald "Motivasi adalah perubahan energi dalam diri seseorang yang ditandai dengan munculnya "feeling" dan didahului dengan tanggapan terhadap adanya tujuan" (Sardimaan, 20I4:73). dapat disimpulkan bahwa motivasi merupakan sebuah dorongan yang dialami oleh seseorang untuk melakukan suatu perbuatan yang disengaja maupun tidak disengaja untuk mencapai tujuan tertentu.

Motivasi dan belajar merupakan dua hal yang saling mempengaruhi. Belajar merupakan perubahan tingkah laku secara relatif permanen dan secara potensial terjadi sebagai hasil praktik atau penguatan yang dilandasi tujuan untuk mencapai tujuan tertentu. "Motivasi belajar dapat timbu karena faktor intrinsik, berupa hasrat dan keinginan berhasil dan dorongan kebutuhan belajar, harapan akan citacita. Sedangkan faktor ektrinsiknya adanya penghargaan, lingkungan belajar yang kondusif, dan kegiatan belajar yang menarik" (Uno, 2016: 23). "Motivasi belajar merupakan kondisi psikologis yang mendorong seseorang untuk belajar” (Khodijah, 20I4: 150).

Motivasi adalah segi kejiwaan yang mengalami perkembangan, artinya terpengaruh oleh kondisi fisiologis dan kematanagan psikologis siswa. Dimyati dan Mudjiyono (2009: 96), mengemukakan beberapa unsur yang memepengaruhi motivasi dalam belajar, yakni : I) Cita-cita dan aspirasi siswa. Cita-cita akan memperkuat motivasi belajar siswa baik intrinsik maupun ekstrinsik. 2) Kemampuan siswa. Keinginan seorang anak perlu dibarengi dengan kemampuan atau kecakapan dalam pencapaiannya. 3) Kondisi siswa. Kondisi siswa yang meliputi kondisi jasmani dan rohani mempengaruhi motivasi belajar. 4) Kondisi lingkungan siswa. Lingkungan siswa dapat berupa keadaan alam, lingkungan tempat tinggal, pergaulan sebaya, dan kehidupn bermasyarakat (kompri, 20I5: 23I)

Didalam kegiatan belajar mengajar peranan motivasi baik intrinsik maupun ekstrinsik sangat diperlukan. Dengan motivasi, pelajar dapat mengembangkan aktivitas dan inisatif, dapat mengarahkan dan memelihara ketekunan dalam melakukan kegiatan belajar. Ada beberapa bentuk dan cara untuk menumbuhkan motivasi dalam kegiatan belajar disekolah" (Sardiman, 20I4: 9I) yaitu : memberi angka, hadiah, kompetensi, Ego-Invholvement, memberi ulangan, meberitahu hasil, pujian, hukuman, hasrat untuk belajar, minat dan tujuan yang diakui.

\section{Metode Penelitian}

Pendekatan yang digunakan pada penelitian ini menggunakan pendekatan kuantitatif dengan metode survey. Survei adalah metode riset dengan menggunakan kuesioner sebagai pengumpulan datanya" (Bungin, 2006: 59). Dalam penelitian ini jumlah sampelnya berjumlah 56 siswa, maka teknik pengambilan sampel yang digunakan adalah sampling jenuh. Sampling jenuh adalah "Teknik penentuan sampel bila semua anggota populasi digunakan sebagai sampel” (Sugiyono, 2013: 68). 
Teknik pengumpulan data pada penelitian yaitu dengan menggunakan wawancara yang dilakukan kepada guru kelas IV SDN poris gaga 05, angket (kuisioner) yang diberjumlah 30 butir pernyataan per variabel dan diberikan kepada seluruh siswa kelas IV di SDN Poris gaga 05, dan observasi yang dilakukan di kelas IV SDN poris gaga 05 pada awal penelitian.

Instrumen penelitian pada penelitian ini yaitu dengan variabel terkait $(Y)$ adalah minat belajar dan variabel bebas $(\mathrm{X})$ adalah motivasi belajar. yang dimana pada kisi-kisi variabel terikat $(\mathrm{Y})$ terdapat 8 indikator yang berbeda dengan jumlah butir pernyataan 30 butir dan dalam bentuk 16 butir pernyataan positif dan I4 utir pernyataan negatif. Dan pada kisi-kisi variabel bebas (X) terdapat 4 indikator yang berbeda dengan jumlah butir pernyataan 30 butir dan dalam bentuk 16 butir pernyataan positif dan I4 butir pernyataan negatif. Instrumen penelitian variabel $\mathrm{X}$ dan variabel $\mathrm{Y}$ dilakukan expert judgement, validitas dan realibilta untuk mengetahui valid atau tidaknya instrumen penelitian tersebut.

Teknik analisis data dalam penelitian kuantitatif menggunakan statistik. Dalam analisis data ini peneliti menggunakan statistik inferensial. Statistik inferensial merupakan teknik statistik yang digunakan untuk menganalisis data sampel dan hasilnya diberlakukan untuk populasi. Langkahlangkah analasis inferensial sebagai berikut : I) Menduga model regresi 2) uji prasyarat analisis yang terdiri dari uji normalitas dan uji homogenitas 3) Uji model regresi / linieritas regresi 4) Uji signifikansi regresi 5) Uji koefisien korelasi ( Uji Tingkat Keeratan dengan uji t).

\section{Hasil dan Pembahasan}

Data yang akan di deskripsikan adalah data dari responden yang menyangkuta hubungan antar motivasi belajar dengan minat belajar yang terdiri dari dua variabel yaitu variabel $\mathrm{X}$ mewakili Motivasi belajar dan variabel Y mewakili Minat belajar. kedua variabel tersebut dianalisis, apakah terdapat hubungan atau tidak, jika terdapat hubungan berapa persenkah signifikasi keterkaitannya. Dari hasil analisis data maka dapat diketahui hasil motivasi belajar dan minat belajar yaitu :

Tabel I. Distribusi minat belajar

\begin{tabular}{ccccccc}
\hline No. & Skala interval & F & (Xi) & Xi $^{2}$ & F.Xi & $(\%)$ \\
\hline I. & $68-73$ & 4 & 70,5 & 4970,25 & 282 & 7 \\
2. & $74-79$ & 8 & 76,5 & 5852,25 & $6 \mathrm{I} 2$ & I4 \\
3. & $80-85$ & I0 & 82,5 & 6806,25 & 825 & I8 \\
4. & $86-9 \mathrm{I}$ & 4 & 88,5 & 7832,25 & 354 & 7 \\
5. & $92-97$ & II & 94,5 & 8930,25 & 1039,5 & 20 \\
6. & $98-103$ & I3 & 100,5 & 10100,25 & 1306,5 & 23 \\
7. & $104-109$ & 6 & 106,5 & 11342,25 & 639 & II \\
\hline & $\sum$ & 56 & 619,5 & 55833,75 & 5058 & I00 \\
\hline
\end{tabular}

Dari tabel distribusi minat belajar diatas dapat diketahu bahwa frekuensi teranyak terdapat pada kelas interval 98 - I03 dengan frekuensi I3.

Tabel 2. Distribusi motivasi belajar

$\begin{array}{lllllll}\text { No. Skala interval } & \mathrm{F} & (\mathrm{Xi}) & \mathrm{Xi}^{2} & \mathrm{~F} . \mathrm{Xi} & \mathrm{f.Xi}^{2} & (\%)\end{array}$




\begin{tabular}{|c|c|c|c|c|c|c|c|}
\hline No. & Skala interval & $\mathrm{F}$ & (Xi) & $\mathrm{Xi}^{2}$ & F.Xi & f. $\mathbf{X i}^{2}$ & $(\%)$ \\
\hline I. & $67-72$ & 5 & 69,5 & 4830,25 & 347,5 & 24151,25 & 9 \\
\hline 2. & $73-78$ & 6 & 75,5 & 5700,25 & 453 & 34201,5 & I I \\
\hline 3. & $79-84$ & $\mathrm{I} 2$ & $8 \mathrm{I}, 5$ & 6642,25 & 978 & 79707 & $2 \mathrm{I}$ \\
\hline 4. & $85-90$ & I I & 87,5 & 7656,25 & 962,5 & 84218,75 & 20 \\
\hline 5. & $9 I-96$ & I4 & 93,5 & 8742,25 & I309 & I2239I,5 & 25 \\
\hline 6. & $97-102$ & 7 & 99,5 & 9900,25 & 696,5 & 69301,75 & I3 \\
\hline \multirow[t]{2}{*}{7.} & I03- I08 & I & $\mathrm{I05,5}$ & I I I 30,25 & $\mathrm{I05,5}$ & I I I30,25 & 2 \\
\hline & $\sum$ & 56 & 612,5 & 54601,75 & 4852 & 425102 & I00 \\
\hline
\end{tabular}

Dari tabel distribusi motivasi belajar didaptakan bahwa frekuensi tertinggi yaitu I4 pada kelas interval 9I - 96.

Berdasarkan hasil analisis data, seperti : uji validitas, reliabilitas, uji normalitas, homogenitas, dan korelasi regresi maka peneliti mendapatkan hasil sebagai berikut : pada uji coba validitas motivasi belajar hasilnya 27 pernyataan valid dan 3 pernyataan tidak valid, lalu peneliti melakaukan uji coba lagi untuk pernyataan yang belum valid sampai akhirnya pernyataan tersebut valid semua. Pada uji coba instrumen motivasi belajar peneliti mendapatkan nilai $\mathrm{r}=0,6 \mathrm{I7}$ dengan tingkat hubungan tinggi dan mendapatkan nilai realibilitas rII $=0,746$ dengan tingkat hubungan tinggi. Pada uji coba minat belajar hasilnya terdapat 24 pernyataan valid dan 6 pernyataan tidak valid, lalu penenliti melakukan uji coba ulang untuk pernyataan yang belum valid sampai akhirnya valid semua. Pada uji coba instrumen minat belajar peneliti mendapat nilai $\mathrm{r}=0,635$ dengan tingkat hubungan tinggi dan mendapat nilai reliabilitas $\mathrm{rI} I=0,779$ dengan tingkat hubungan tinggi.

Pada hasil nilai uji normalitas motivasi belajar chiX2 $=4,006<$ Ftabel 12,592 yang artinya motivasi belajar berdistribusi normal. Dan untuk nilai chi kuadrat minat belajar chiX2 = II,03 I < Ftabel $=12,592$ yang artinya minat belajar berdistribusi normal. Selanjutnya dalam hasil homogenitas motivasi belajar mendapatkan hasil Fhitung $=\mathrm{I}, 387<$ Ftabel $=\mathrm{I}, 88$ dengan terima Ho yang artinya motivasi belajar memiliki varian yang sama atau homogen. Dan hasil homogenitas minat belajar mendapatkan hasil Fhitung $=2,067>$ Ftabel $=1,88$ maka tolak Ho yang artinya minat belajar memiliki varian yang berbeda atau tidak homogen.

Selanjutnya dalam hasil nilai koefisien persamaan regresinya adalah $\hat{y}=1,528+1,024 X$ artinya jika minat belajar naik I\% maka motivasi belajar akan naik I,024. Hal tersebut dapat dikatakan bahwa kenaikan minat belajar akan mempengaruhi motivasi belajar. Setelah melakukan uji regresi dengan uji $\mathrm{F}$ maka diperoleh Fhitung $>$ Ftabel atau 204,9378 > 4,02 maka H0 ditolak dan disimpulkan terdapat hubungan signifikan antar motivasi belajar dengan minat belajar. Setelah melakukan uji $\mathrm{F}$ maka peneliti melakukan uji koefisen korelasi dengan nilai $\mathrm{r}=0,889$ maka dari nilai $\mathrm{r}$ didapatkan nilai koefisien determinasinya atau pengkuadratan dari koefisien korelasi $(0,889) 2 \mathrm{x}$ $100 \%=79,1 \%$ yang artinya meningkatnya motivasi belajar siswa akan membawa peningkatan pada minat belajar siswa dan sebaliknya menurunnya motivasi belajar siswa akan membawa penurunan pada minat belajar siswa. Motivasi belajar merupakn faktor yang mempengaruhi minat belajar sebesar 79,I\% dan 21,9\% dipengaruhi oleh faktor lainnya. Hal ini sama dengan teori (Rahmadita, 20I4: I2) bahwa salah satu faktor yang mempengaruhi minat belajar adalah motivasi belajar, sehingga kenaikan motivasi pada diri siswa akan mempengaruhi kenaikan minat belajar siswa juga. 
Pentingnya motivasi untuk belajar adalah karena motivasi merupakan kekuatan yang mendorong sesorang untuk mencapai tujuan tertentu. motivasi sangat diperlukan dalam belajar, karena pada dasarnya seorang siswa akan termotivasi dalam belajar untuk mencapai keinginannya. Tanpa adanya motivasi seorang anak atau peserta didik tidak akan merasa nyaman dalam belajar, dan anak tersebut juga biasanya tidak mau mengikuti proses pembelajaran. Oleh karena itu agar dapat meningkatkan minat belajar siswa motivasi belajar sangat diperlukan agar proses pembelajaran berjalan dengan lancar.

\section{Kesimpulan}

Berdasarkan hasil penelitian yang telah dilakukan dengan judul skripsi " Hubungan Antara Motivasi Belajar dengan Minat Belajar Siswa Kelas IV SDN Poris gaga 05 Kota Tangerang” dan untuk menjawab pertanyaan penelitian yang diajukan pada rumusan masalah pada bab I maka berikut ini peneliti mencoba memberikan kesimpulan bahwa: I) Terdapat hubungan yang signifikan antara motivasi belajar dengan minat belajar siswa kelas IV SDN Poris gaga 05 Kota Tangerang dengan nilai $\mathrm{r}$ hitung 0,889 lebih besar dari $\mathrm{r}$ tbel 0,264 atau 0,89 $>0,264$ dengan tingkat hubungan sangat kuat. 2) Terdapat hubungan yang positif antaar motivasi belajar dengan minat belajar siswa kelas IV SDN Poris gaga 05 Kota Tangerang dengan koefisien determinasi yaitu 0,889 x 0,889 × $100=$ $0,791 \%$.

\section{Referensi}

Bungin, B. (2006). Teknik Praktis Riset Komunikasi. Jakarta: Prenada Media Group

Djaali, H. (2014). Psikologi Pendidikan. Jakarta: Bumi Aksara

Djamarah, S.B (20I I). Psikologi Belajar. Jakarta: Rineka Cipta

Hidayat, S. (2013). Teori dan Prinsip Pendidikan. Tangerang: Pustaka Mandiri

Khodijah, N. (20I4). Psikologi Pendidikan. Jakarta: Rajawali Pers

Kompri. (2015). Motivasi Pembelajaran Perspektif Guru dan Siswa. Bandung: PT Remaja Rosdakarya

Prahmadita, A.D. (2014). Faktor-faktor Yang Mempengaruhi Minat Siswa Untuk Mengikuti Ekstrakurikuler Drumband di SMP Negeri I Sleman. Fakultas Bahasa dan Seni. Yogyakarta: Universitas Negeri Yogyakarta http://eprints.uny.ac.id/I7679/I/Aulia\%20Devi\%20Prahmadita\%200820824I0I2.pdf

Purwanto, M.N. (2013). Psikologi Pendidikan. Bandung: PT Remaja Rosdakarya

Sardiman. (20I4). Interaksi dan Motivasi Belajar Mengajar. Jakarta:Rajawali

Slameto. (2013). Belajar dan Faktor-faktor yang Mempengaruhinya. Jakarta: Rineka Cipta

Sugiyono. (2013). Metode Penelitian Kuantitatif, Kualitatif dan Kombinasi (Mixed Methods). Bandung: Alfabeta

Sugiyono. (2013). Statistik Untuk Penelitian. Bandung: Alfabeta

Susanto, A. (2013). Teori Belajar dan Pembelajaran di Sekolah dasar. Jakarta: Prenadamedia Group

Uno, H.B. (2016). Teori Motivasi dan Pengukurannya. Jakarta: PT Bumi Aksara.

Warsito. (2016). Diktat Statistik., Tangerang: Univeristas Muhammadiyah Tangerang 